\title{
PENGUJIAN AKURASI kVp DAN LINEARITAS PADA PESAWAT SINAR-X DI LABORATORIUM PRODI DIPLOMA III TEKNIK RADIODIAGNOSTIK DAN RADIOTERAPI PURWOKERTO
}

\section{ACCURACY kVP AND LINEARITY TESTING X-RAY UNIT IN LABORATORY OF DIPLOMA III TECHNIQUE RADIODIAGNOSTIC AND RADIOTHERAPY PURWOKERTO}

\author{
Asri Indah A. ${ }^{1)}$, Indra Kartika N. ${ }^{2)}$, Panji W. Nurcahyo ${ }^{3)}$ \\ ${ }^{1,2,3)}$ Health Polytechnic of Semarang-Indonesia \\ e-mail: asriinda22@yahoo.co.id
}

\begin{abstract}
Background: Quality control is part of the quality assurance program related to the techniques used in the monitoring the maintenance of the technical elements of the system that affect picture quality. KVp accuracy and linearity (test mAs) is one of the components which are tested on the routine test performance evaluations. The X-ray Biomedical International unit brands BRG 100 RF of Laboratory Diploma in Mechanical Radiodiagnostic and Radiotherapy Purwokerto have not been tested yet. The objectives of this study are to determine suitability output $\mathrm{kVp}$ accuracy and linearity that have been beeing setting at control panel X-ray unit.

Methods: This research belongs to a quantitative research which was conducted in April 2016 at the Laboratory of Radiodiagnostic Diploma Engineering and Radiotherapy Purwokerto on X-ray Biomedical International unit brands BRG 100 RF. The tests carried out two stages of

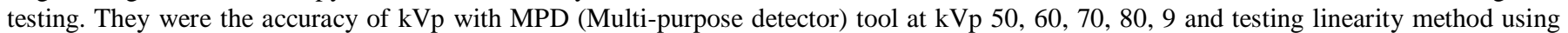
Stepwedge and Reciprocity mAs Densitometer at $55 \mathrm{kVp}, 10 \mathrm{mAs}$ with a variation of $200 \mathrm{~mA}$ and 100 . The results was analysed based on the quality control examining contained in KMK RI No.1250, the value of deviation accuracy of $\mathrm{kVp} 6 \%$ and for linearity deviation value (mAs) $\leq \pm 0.1$.

Result: The test results showed that there are some deviations occur repeatedly on the accuracy of kVp on the value of eksposi 50, 60, 70, 80, 90 , are $0.78 \%, 1.31 \%, 1.32 \%, 1.63 \%, 2.5 \%$, but the deviation is still within the allowable limits that does not exceed $10 \%$. The linearity testing showes that there are differences in optical density values on the radiograph with variations $\mathrm{mA}$ and $\mathrm{s}$ which are still within the allowable limit that is $\leq \pm 0.1$.

Conclusion: Based on the result of $\mathrm{kVp}$ accuracy and linearity test, the deviation value is still within the tolerance limit or still in accordance with the permissible tolerance according to KMK RI 1250 about quality control testing parameter
\end{abstract}

Keywords: Quality Control, Accuracy kVp, Linearity

\section{PENDAHULUAN}

Salah satu pemanfaatan pesawat sinar-X adalah untuk radiografi. Dalam menjamin diperolehnya hasil radiograf dan kinerja pesaswat sinar-X yang optimal dengan dosis radiasi yang minimum bagi pasien, pekerja radiasi dan masyarakat maka perlu dilakukannya program quality control. Menurut Papp (2006), quality control adalah bagian dari program quality assurance yang berhubungan dengan teknik yang digunakan dalam pemantauan dan pemeliharaan unsur-unsur teknis dari sistem yang mempengaruhi kualitas gambar.

Program quality control meliputi pengujian Filter, Kolimasi, Ukuran Focal Spot, Akurasi kVp, Akurasi Waktu Eksposi, Lienaritas, Reproduksibilitas Sinar-X, Intensifiying Screen, Pakaian Pelindung, Film Iluminato (Papp 2006). kV dan mAs merupakan faktor yang sangat mempengaruhi kuantitas, kualitas sinar-X dan mempengaruhi hasil radiograf. Menurut KMK RI No.1250, pengujian akurasi kVp dan linearitas (uji mAs) dilakukan setiap 1 tahun sekali untuk menjaga performance dan kinerja pesawat sinar-X selalu dalam kondisi yang optimal.
Sejak dipasang dan dioperasikannya pesawat sinar-X merk Biomedical International BRG 100 RF pada tahun 2013 di Laboratorium Prodi Diploma III Teknik Radiodiagnostik dan Radioterapi Purwokerto belum pernah dilakukan pengujian terhadap komponen $\mathrm{kVp}$ dan $\mathrm{mAs}$ baik oleh pihak berkualifikasi yang memiliki ijin uji kesesuaian dari Bapeten atau oleh pihak lain sebagai pengguna pesawat sinar-X tersebut padahal di Laboratorium Prodi Diploma III Teknik Radiodiagnostik dan Radioterapi Purwokerto memiliki alatalat yang dapat digunakan untuk uji linearitas yaitu Stepwedge Alumunium dan Lead blocker.

Penelitian ini bertujuan untuk mengetahui hasil pengujian akurasi $\mathrm{kVp}$ dan linearitas pada pesawat sinar-X di Laboratorium Prodi Diploma III Teknik Radiodiagnostik dan Radioterapi Purwokerto, dan untuk mengetahui kesesuaian hasil pengujian akurasi $\mathrm{kVp}$ dan linearitas pada pesawat sinarX di Laboratorium Prodi Diploma III Teknik Radiodiagnostik dan Radioterapi Purwokerto terhadap parameter pengujian quality control. 


\section{METODE}

Jenis penelitian yang dilakukan adalah penelitian kuantitatif dengan pendekatan observasional. Penelitian dilaksanakan pada bulan April 2016 di Laboratorium Prodi Diploma III Teknik Radiodiagnostik dan Radioterapi Purwokerto. Subyek Penelitian pesawat sinar-X merk Biomedical International BRG 100 RF di Laboratorium Prodi Diploma III Teknik Radiodiagnostik dan Radioterapi Purwokerto. Pengumpulan data diperoleh dengan carai observasi, pengukuran dan dokumentasi.

\section{HASIL}

Hasil pengukuran yang didapat dari interval arus tabung 40-90 kVp dengan mAs 10 yang disajikan dalam bentuk tabel sebagai berikutHasil pengukuran pada $40 \mathrm{kVp}$ tidak dapat terdeteksi oleh alat ukur Multy Purpose Detector dikarenakan respon minimum yang dapat diterima oleh detector yang digunakan adalah sebesar $45 \mathrm{kVp}$ sehingga hasil keluaran pada $40 \mathrm{kVp}$ tidak dapat terdeteksi dan tidak dimasukan dalam tabel hasil pengukuran.

Tabel 1. Hasil Tabulasi data

\begin{tabular}{ccccc}
\hline eksposi & $\begin{array}{c}\mathrm{kVp} \\
\text { yang } \\
\text { diatur }\end{array}$ & $\begin{array}{c}\text { Rata } \\
\text { keluaran } \\
\text { kvp }\end{array}$ & $\begin{array}{c}\text { Selisih kVp } \\
\text { yang diatur } \\
\text { dan keluaran } \\
\text { kvp }\end{array}$ & $\begin{array}{c}\text { Persentase } \\
\text { penyimpangan } \\
\mathrm{kVp}(\%)\end{array}$ \\
\hline 1 & 50 & 50,39 & 0,39 & $0,78 \%$ \\
2 & 60 & 60,79 & 0,79 & $1,31 \%$ \\
3 & 70 & 70,93 & 0,93 & $1,32 \%$ \\
4 & 80 & 81,31 & 1,31 & $1,63 \%$ \\
5 & 90 & 92,30 & 2,30 & $2,5 \%$
\end{tabular}

Tabel 2. Hasil pengujian linearitas

\begin{tabular}{cccc}
\hline $\begin{array}{c}\text { No } \\
\text { Step }\end{array}$ & $\begin{array}{c}\text { Rata-Rata Nilai } \\
\text { Densitas Optic } \\
\text { Bidang Pertama } \\
(\mathbf{1 0 0} \text { mA) }\end{array}$ & $\begin{array}{c}\text { Rata-Rata Nilai } \\
\text { Densitas Optic } \\
\text { Bidang Kedua } \\
(\mathbf{2 0 0 m A})\end{array}$ & $\begin{array}{c}\text { Selisih Rata- } \\
\text { Rata Nilai } \\
\text { Densitas } \\
\text { Optic }\end{array}$ \\
\hline 1 & 2,24 & 2,28 & 0,04 \\
2 & 2,36 & 2,39 & 0,03 \\
3 & 2,46 & 2,48 & 0,02 \\
4 & 2,53 & 2,53 & 0 \\
5 & 2,58 & 2,58 & 0 \\
6 & 2,60 & 2,61 & 0,01 \\
7 & 2,62 & 2,62 & 0 \\
8 & 2,63 & 2,62 & 0,01 \\
9 & 2,63 & 2,64 & 0,01 \\
10 & 2,64 & 2,64 & 0 \\
\hline
\end{tabular}

\section{DISKUSI}

Tabel 1 hasil tabulasi data menunjukan masing-masing penyimpangan adalah $(0,78 \% ; 1,31 \% ; 1,32 \% ; 1,63 \% ; 2,5 \%)$, kemudian hasil tersebut dilakukan analisis dengan membandingkan data prosentase penyimpangan dan batasan toleransi parameter KMK RI No. 1250. Sesuai batasan toleransi akurasi $\mathrm{kVp}$ yang terdapat pada tabel parameter program quality control KMK RI No. 1250 sebesar 6\%. Hasil pengukuran dinyatakan masih sesuai denganbatas toleransi yang normal. Jika dilihat dari nilai penyimpangan yang didapatkan kemungkinan terjadi akibat pesawat sinar-X tersebut belum pernah dilakukan kalibrasi awal setelah pemasangan pesawat sinar-x, dan bisa dikarenakan tidak adanya Stabilizer yang mengontrol masuknya arus listrik kedalam pes awat sinar-X sehingga nilai penyimpangan keluaran $\mathrm{kVp}$ mencapai 2,5\%.

Berdasarkan tabel 2 Hasil pengujian linearitas yang didapat dari pengukuran optical density radiograf Stepwedge Bidang Pertama dan Bidang Kedua yang didapatkan selanjutnya dilakukan analisis dengan membandingkan nilai penyimpangan terhadap batasan toleransi parameter uji quality control yang terdapat pada KMK RI No. 1250, nilai toleransi perbedaan optical density yang diperbolehkan harus $\leq 10 \%$ atau $\leq \pm 0,1$. Hasil uji linearitas terdapat nilai penyimpangan terbesar yaitu 0,04 pada step nomor 1 dan nilai penyimpangan terkecil 0,01 yaitu pada step nomor $6,8,9$. Hasil tersebut menunjukan nilai penyimpangan terbesar dalam hasil pengukuran $<0,1$ sehingga dinyatakan masih sesuai dengan batas normal.

\section{SIMPULAN}

Hasil pengujian akurasi $\mathrm{kVp}$ dilakukan terhadap pesawat sinar-X Biomedical International di Laboratorium Prodi Diploma III Teknik Radiodiagnostik dan Radioterapi Purwokerto menggunakan alat MPD (Multy purpose detector) pada interval arus tabung 50-90 kVp dengan mAs 10 berturutturut menunjukan besar nilai penyimpangan $50,39 \mathrm{kVp}$ (0,78\%), 60,79 kVp (1,31\%), 70,93 kVp (1,32\%), 81,31 kVp $(1,63 \%), 92,30 \mathrm{kVp}(2,5 \%)$. Arus tabung $40 \mathrm{kVp}$ tidak dapat terdeteksi oleh alat ukur Multy Purpose Detector yang digunakan karena respon minimum detector adalah $45 \mathrm{kVp}$.

Hasil pengujian akurasi $\mathrm{kVp}$ menunjukan nilai penyimpangan masih dalam batas toleransi atau masih sesuai dengan toleransi yang diijinkan sesuai parameter pengujian quality control KMK RI No. 1250 yaitu pengujian akurasi $\mathrm{kVp}$ penyimpangan harus dibawah $\pm 6 \%$.

Hasil pengujian linearitas pada pesawat sinar-X Biomedical International di Laboratorium Prodi Diploma III Teknik Radiodiagnostik dan Radioterapi Purwokerto pada nilai mAs 10 dengan variasi nilai mA 200, s 0,05 dan mA 100, s 0,1 menghasilkan nilai penyimpangan terbesar adalah 0,04 dan nilai penyimpangan terkecil 0,01 .

Hasil pengujian linearitas menunjukan nilai penyimpangan masih dalam batas toleransi atau masih sesuai dengan toleransi yang diijinkan sesuai parameter pengujian quality control KMK RI No. 1250 yaitu untuk pengujian linearitas perbedaan nilai optical density dari variasi $\mathrm{mA}$ dan $\mathrm{s}$ dengan nilai $\mathrm{mAs}$ sama harus $\leq 0,1$ atau $10 \%$.

\section{DAFTAR PUSTAKA}

Akadi Mukhlis. 2000. Dasar-Dasar Proteksi Radiasi. Rineka Cipta : Jakarta Balai Pendidikan dan Pelatihan Badan Pengawas Tenaga Nuklir Jakarta. Pesawat Sinar-X. 2009. 
Budi, Hidayah. 2009. Pembuatan Perangkat Lunak Berbasis BORLAND DELPHI 7.0 untuk Pengolahan Citra Radiografi Sinar-x.Tangerang.

Bushberg, Jerrold. 2002. The Essential Physics of Medical Imaging Second Edition.Williams and Wilkins : USA.

Bushong, S.C. 2013. Radiologic Science for Technologists Physic, Biology and Protection Tenth Edition. Mosby Inc : USA.

Julia Schmitt, NE. 2001. Quality Control Recommendations for Diagnostic Radiography. Conference of Radiation Control Program Directors, Inc : USA.

Keputusan Menteri Kesehatan Republik Indonesia Nomor 1250/Menkes/Sk/XII/2009..

Papp, Jeffrey. 2006. Quality Management in The Imaging Science. St. Louis Mosby Inc : USA. 